\title{
White Collar Worker
}

National Cancer Institute

\section{Source}

National Cancer Institute. White Collar Worker. NCI Thesaurus. Code C77922.

Refers to workers who perform work that is knowledge intensive and generally nonroutine and unstructured. 